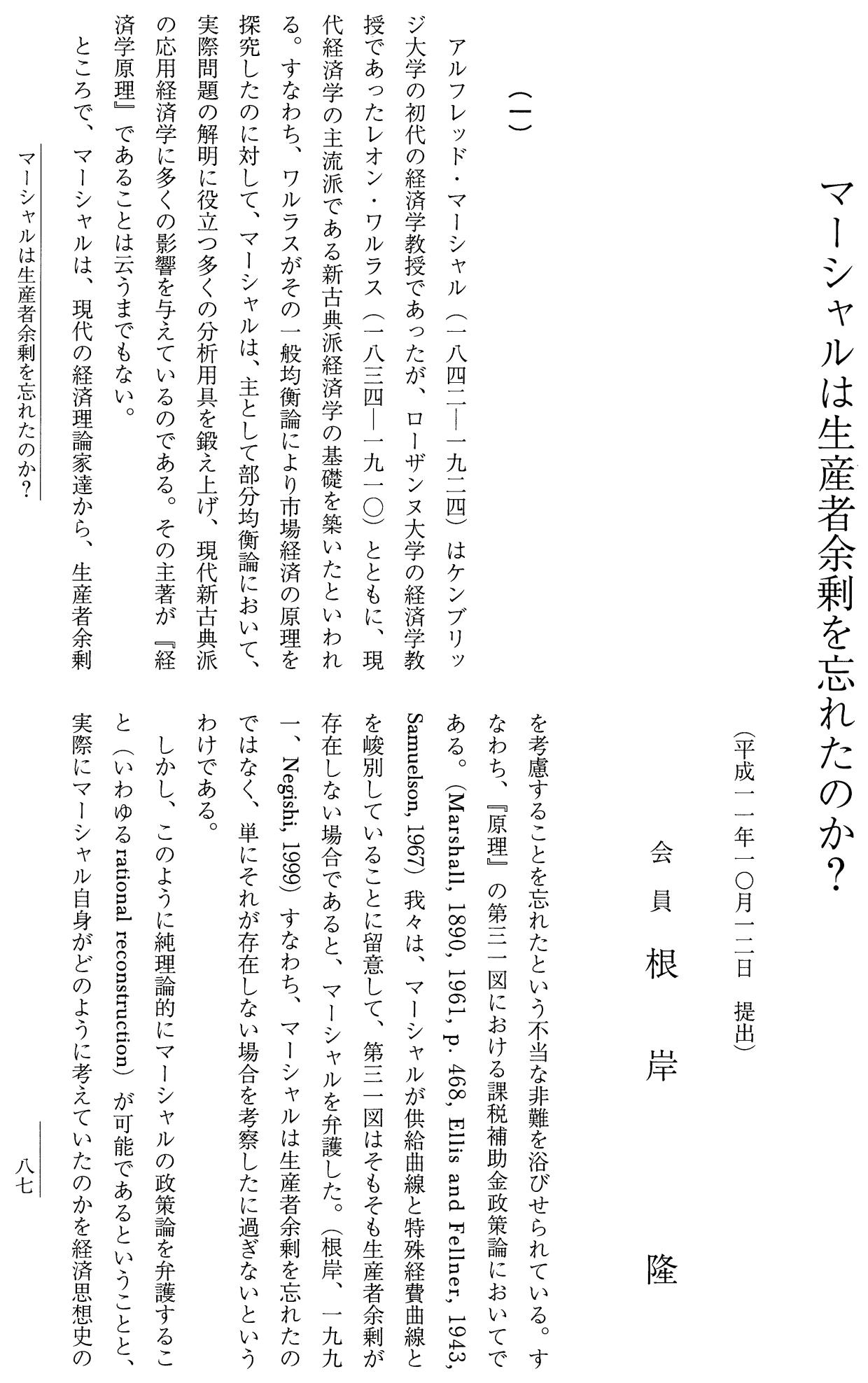


際な ら 易の弁にて四達る節。者論に花㴧税九た公

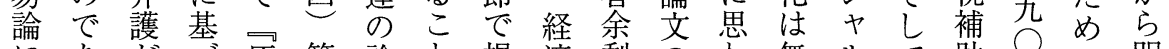
にあがづ原節論と揭斎剰のわ無ルて助こに明 かり後い理と難がげ学、構れ視は、金、はら

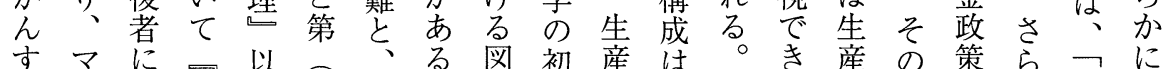

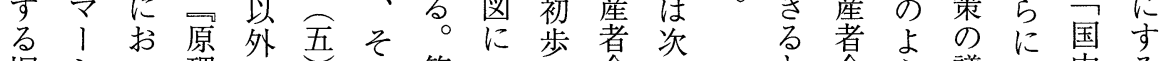

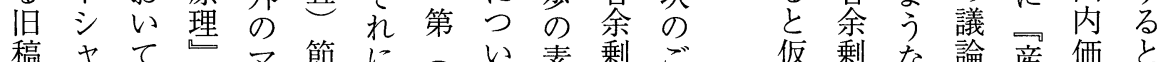
のル試に、と対至て養なと定を考名業值い 部 流 を分れるル論吕でのる概あ 補析るママの文つは後読念る 正 の。現最シ著ので、主節者に

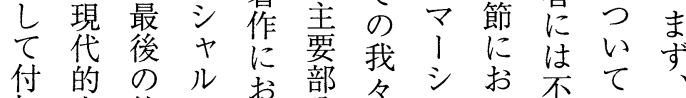

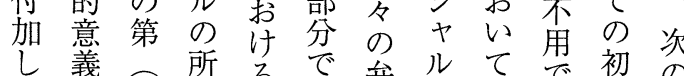

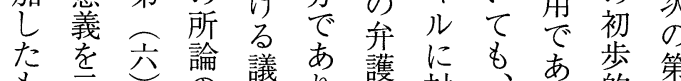

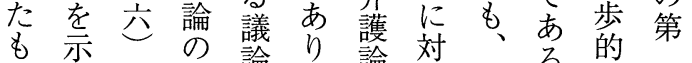

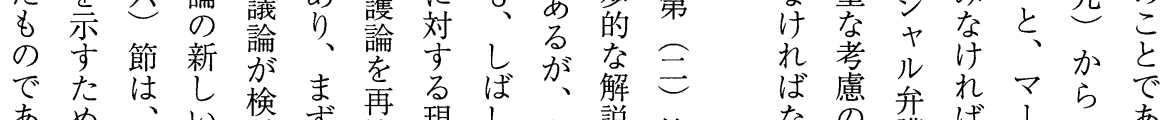

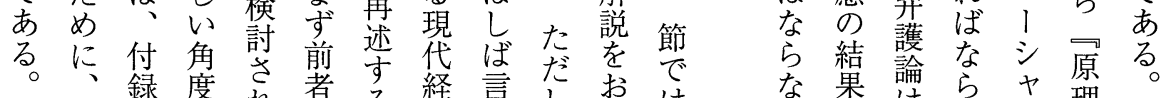

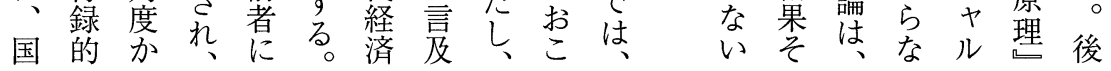

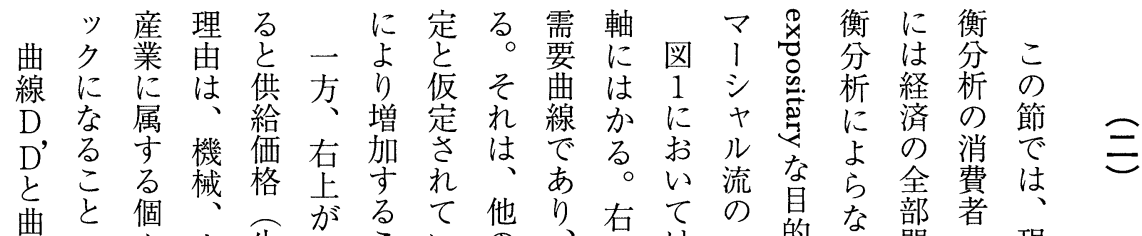

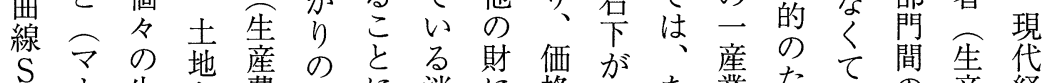

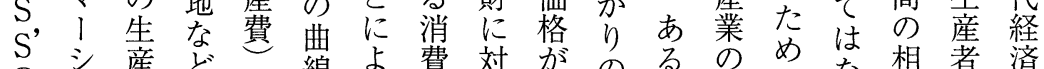

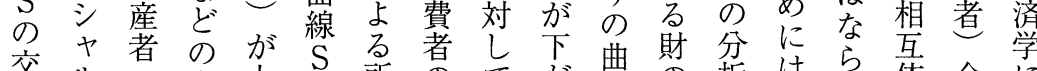

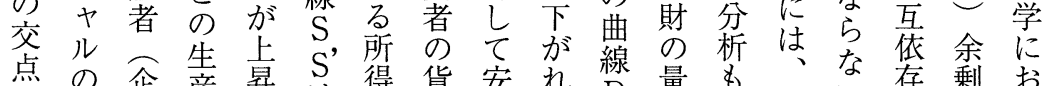
点の企産昇 均 素る給果所に需曲横要事係析る

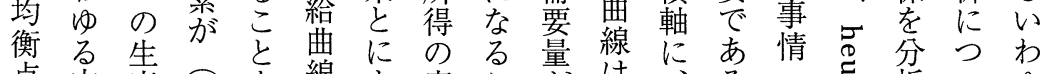

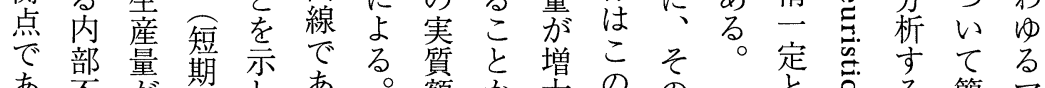

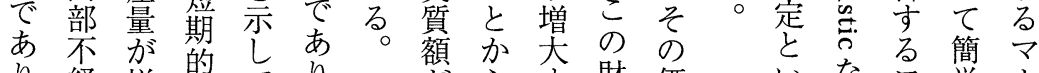

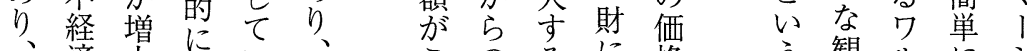

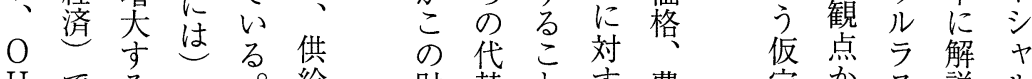
$\mathrm{H}$ でる所給財替々費定㔔説儿

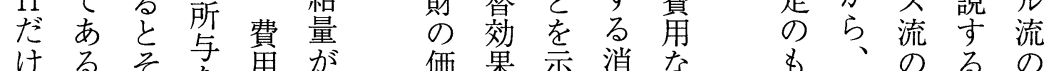

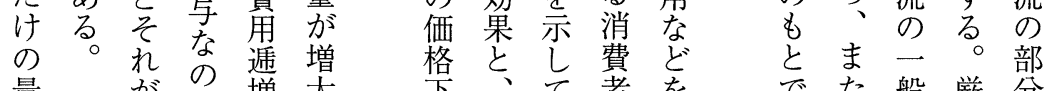

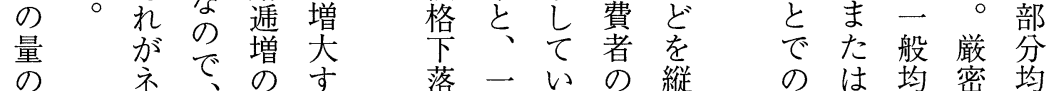



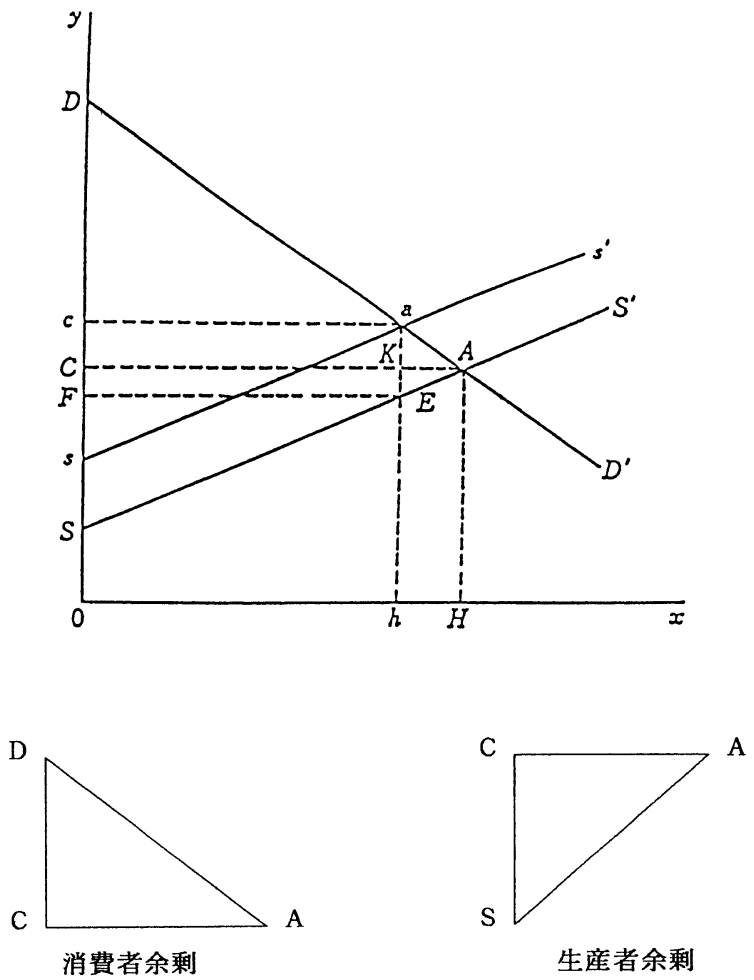

生産者余剩
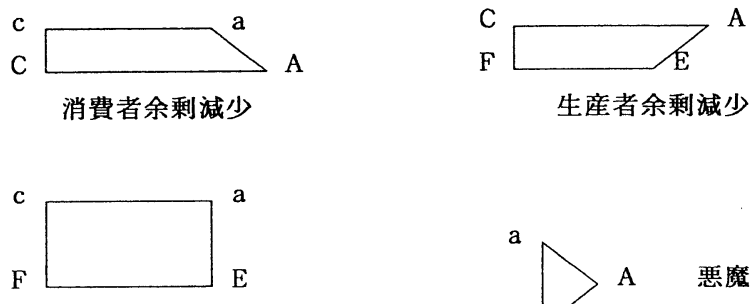

税収

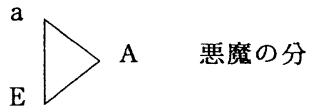

図1

八 


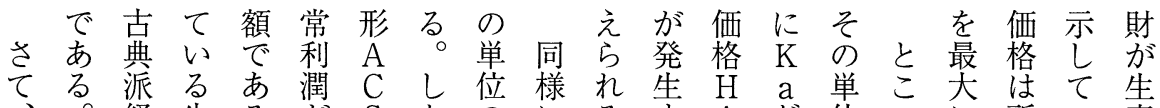

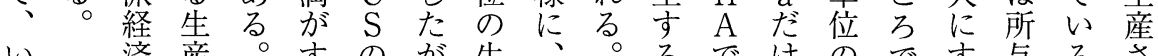

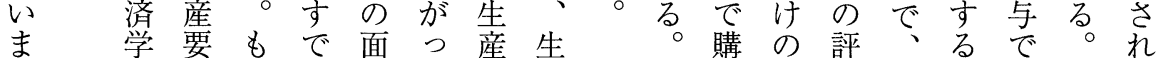
政に素しに積て費産こ入余価消需あ個、

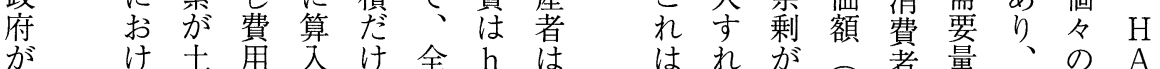
こる地聥さの部 $\mathrm{E}$ O 消ば発支は者量そ競の の リた増れ金でで $\mathrm{h}$ 費至生払 $\mathrm{O}$ 決れ争価 財力けのて額 $\mathrm{O}$ あ 単 者角专つ $\mathrm{h}$ 定に的格

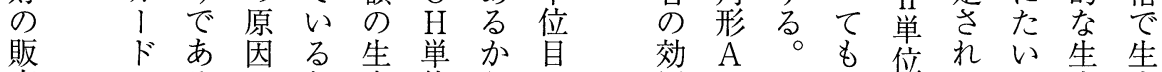

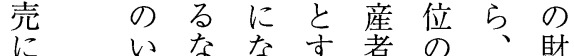
のCたい早いて者者

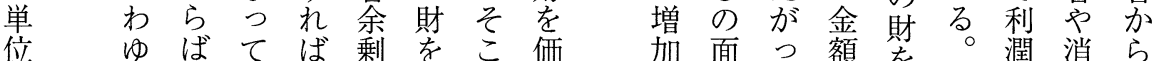
当るっい価に格 り 差こ当こ発格 $\mathrm{E}$

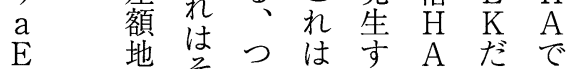

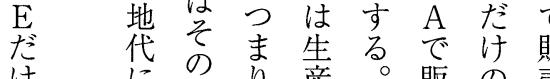
けにの地り産。䟺の筅

の他地齐者生筅余孪

額占あり超費れ㤂と 課はたに過に岕発き 税
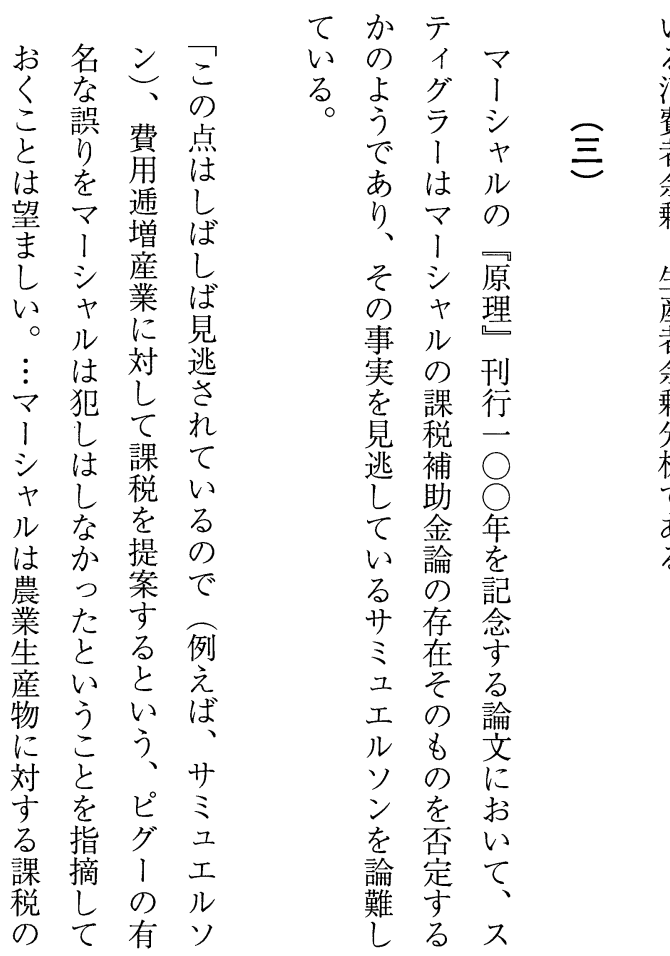

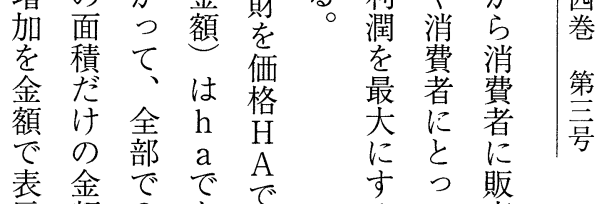
示額 $\mathrm{O}$ あ購 るて 売

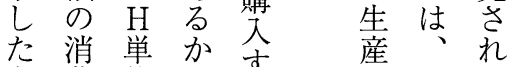

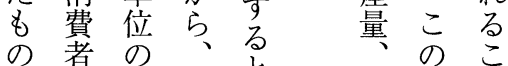
の者の財そ效均と 考剰をこき、角衡を いあいはのれ動を る 以る。 の c 面 ら

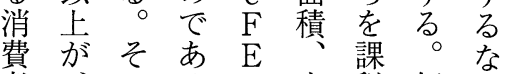
者、のる a 生税価ら 剩、㫘っ面者前格ば

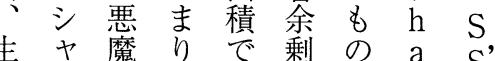

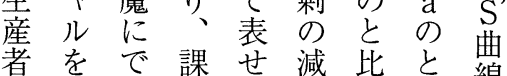
余批も税る少較き線 剩判取に税分守のは 分方ら占収はれ渵 $\mathrm{s}$,

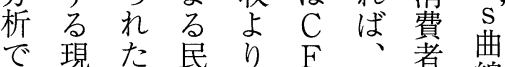
あ代の間导 $\mathrm{E}$ 消余線 る経での 、 A 費剰に 存 ミ在怘 ユそる エの 論

ル \& 文 ソのに を否心 難定?

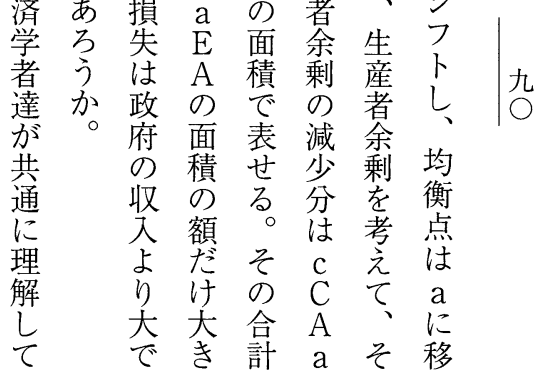



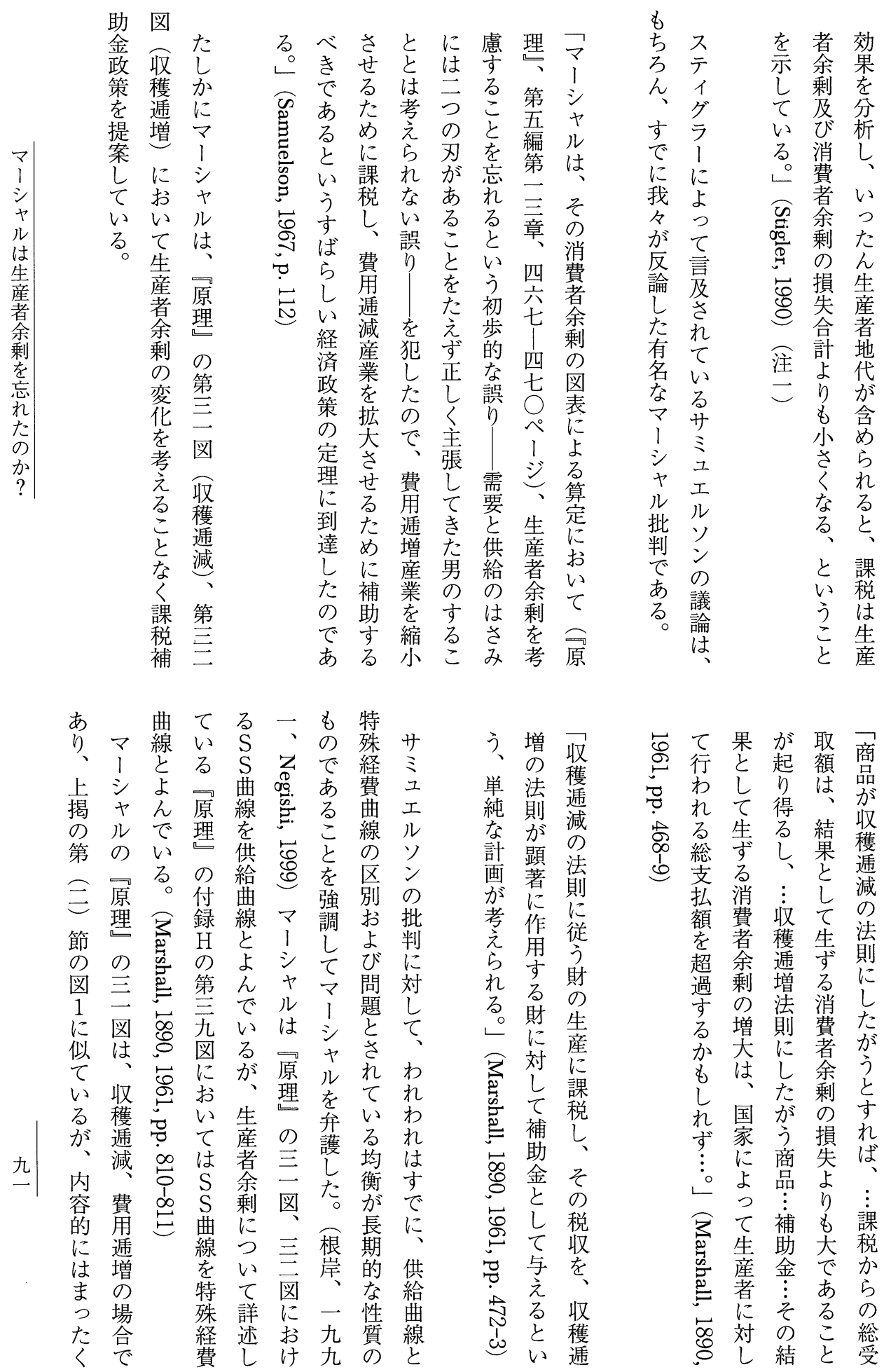


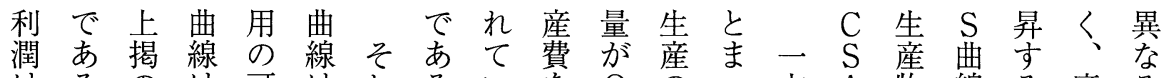

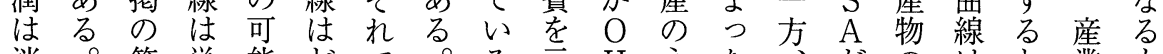

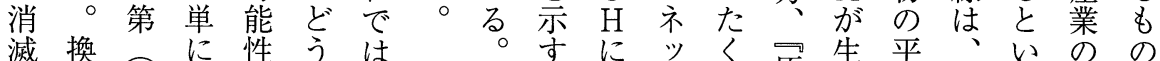

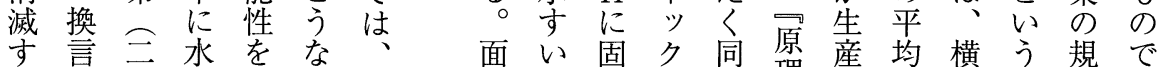
る卞こ平無る原積わ定に瑟者費軸、模あ

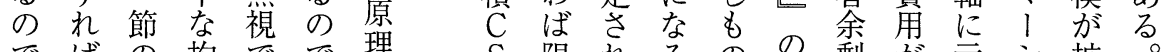
でばの均でで理 S 限往る。の付剩が示シ拡 あ、図衡きあの る費1 価るろ の号生二外あ録示昇れ儿すな 。角を格志う三地産定部り $\mathrm{H}$ 寺专るるのるお マに借線業吕図代費で経、のわ第産外々

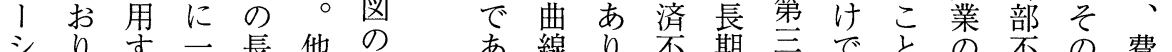

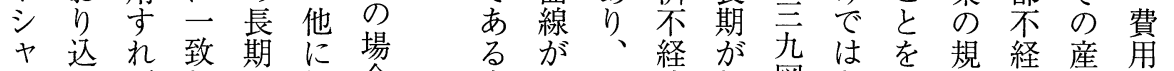
ル多し的転合生 S そ済想図な示模済業聥

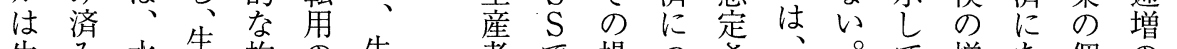

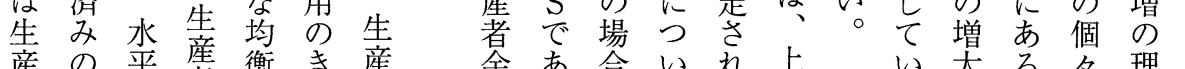

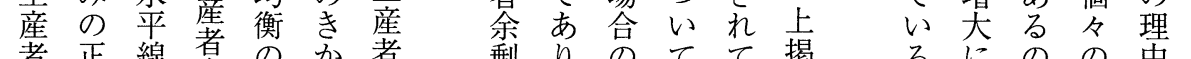

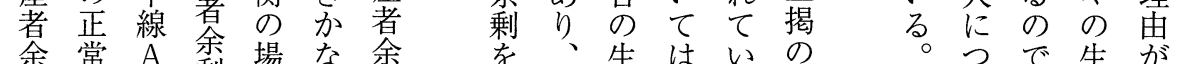

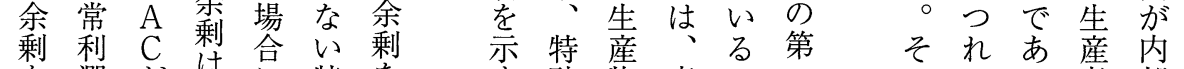

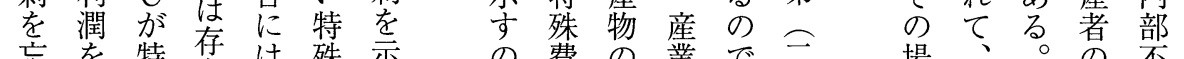
忘を特存は殊示の費の業で三場、。省不 れ越殊在、なす曲各全土合産こ生経

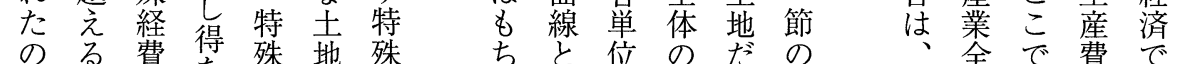

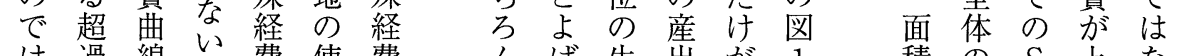

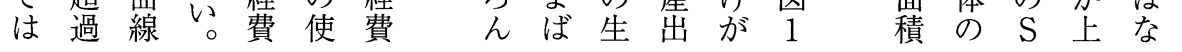

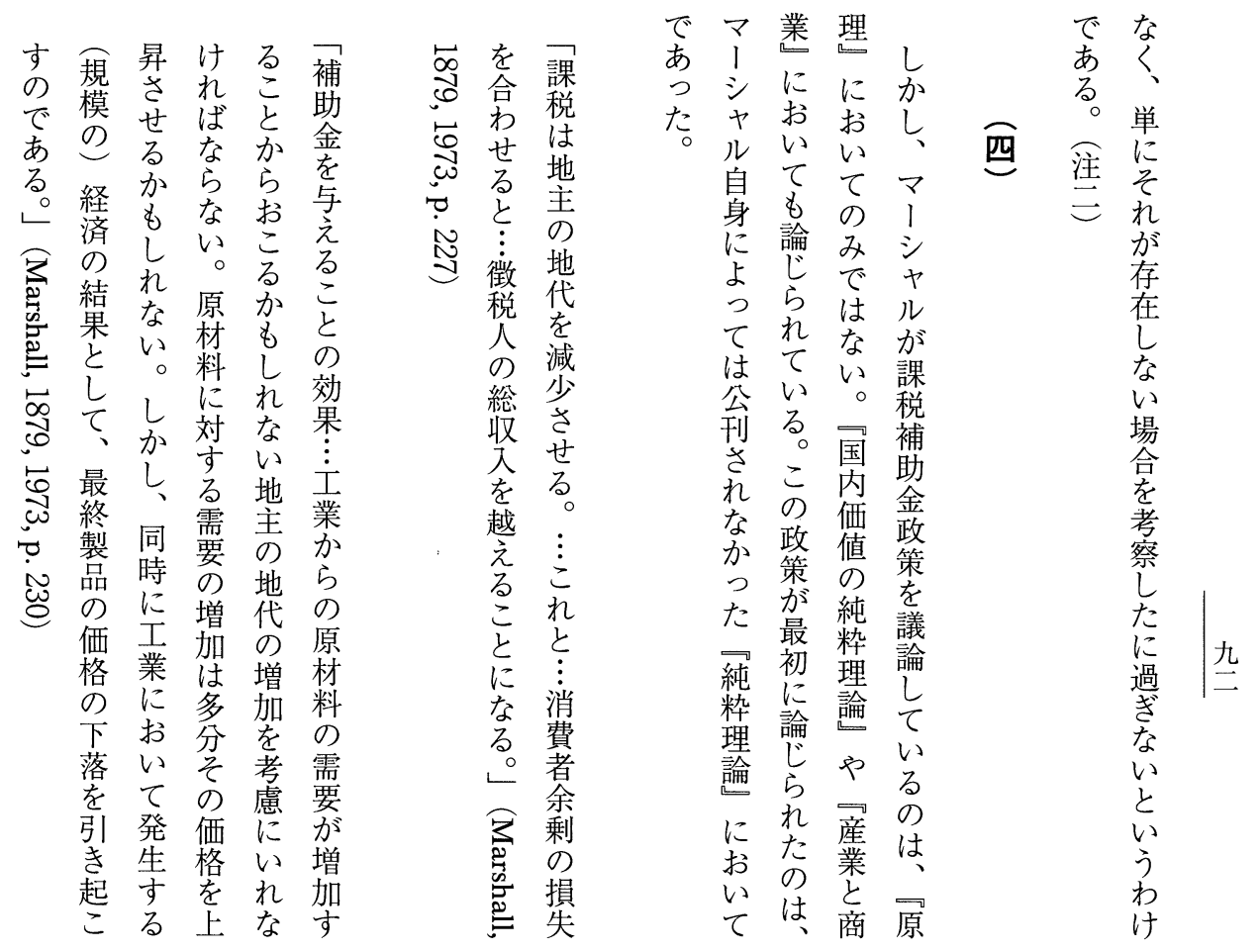




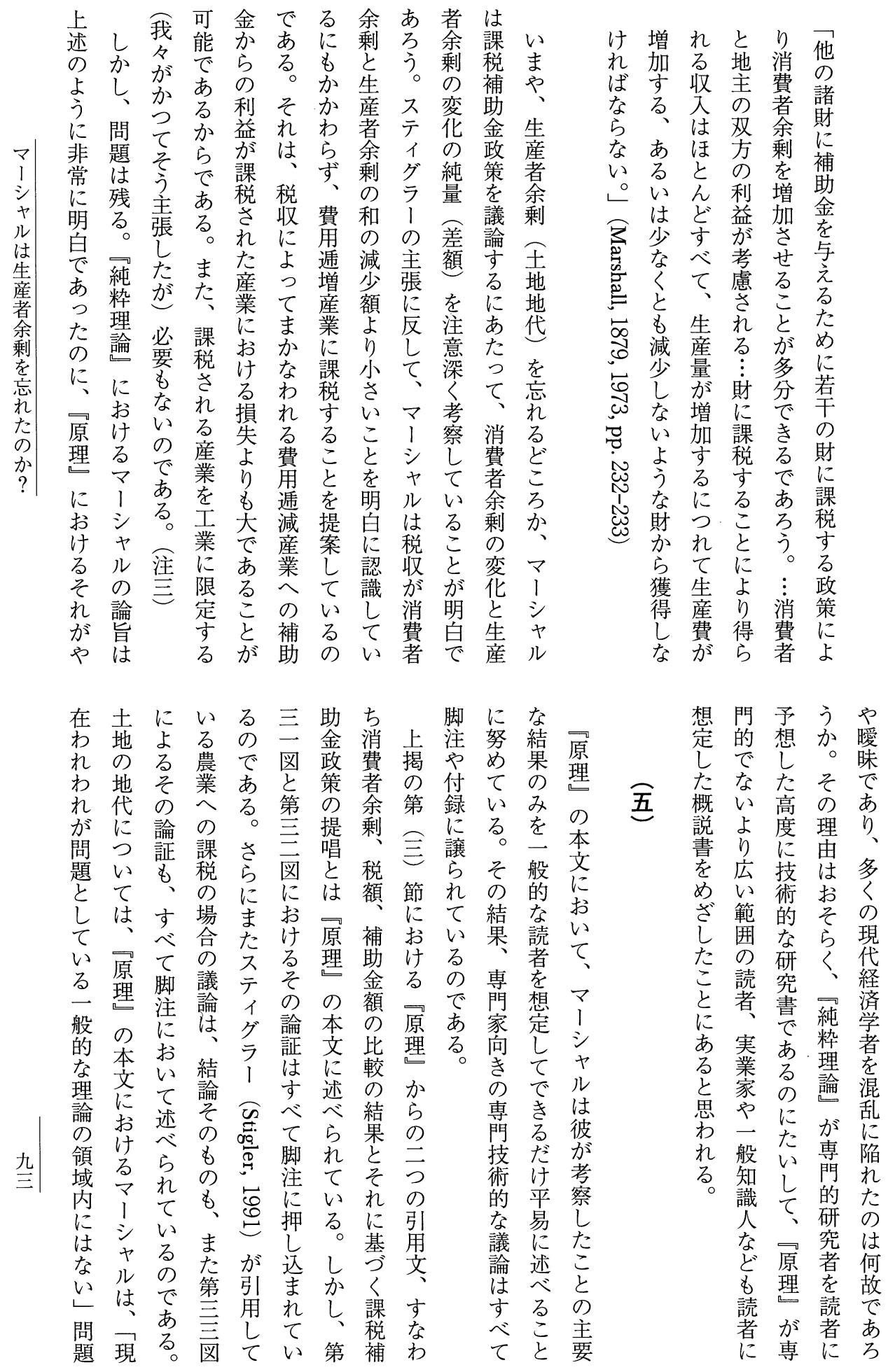




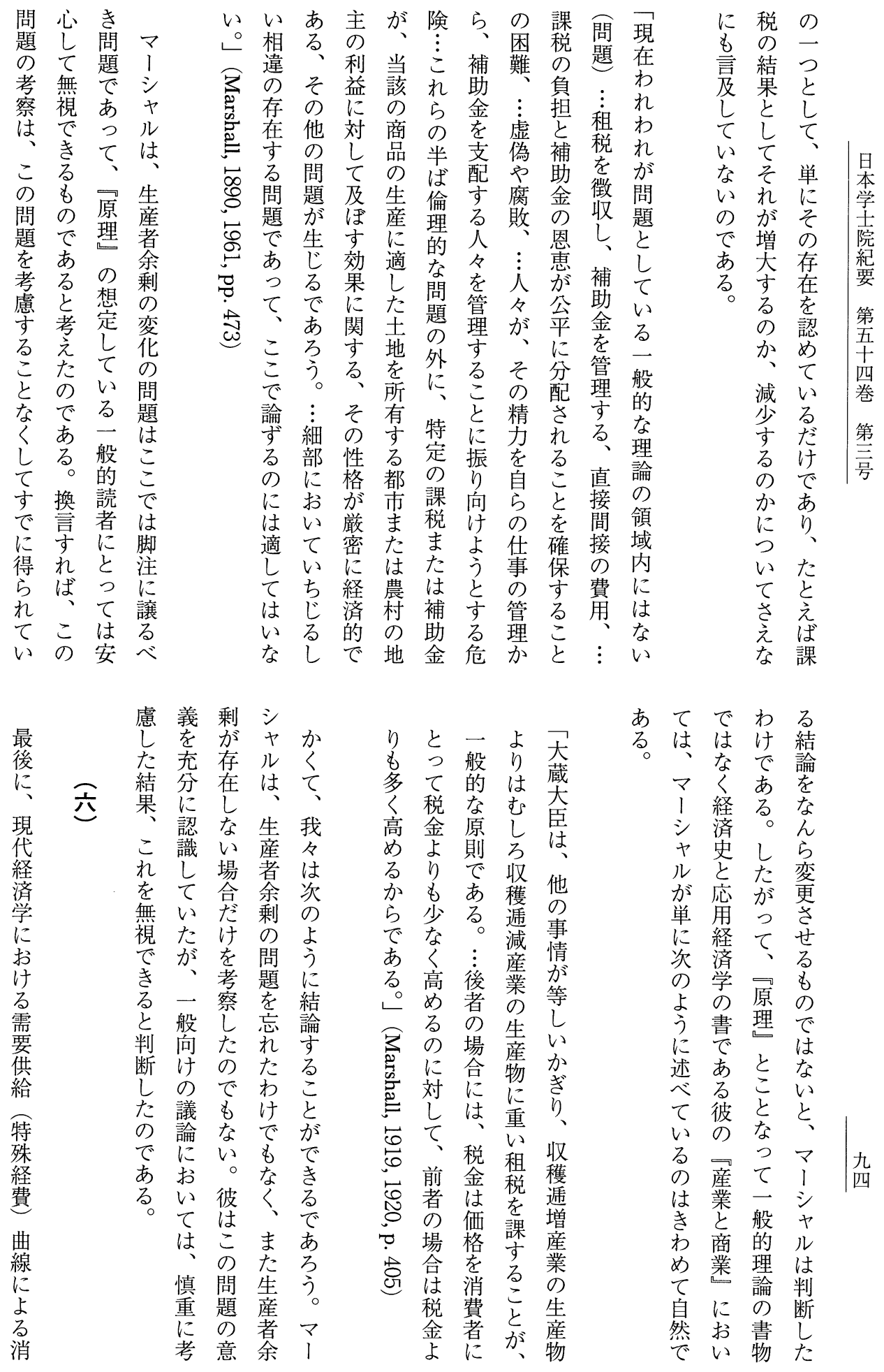




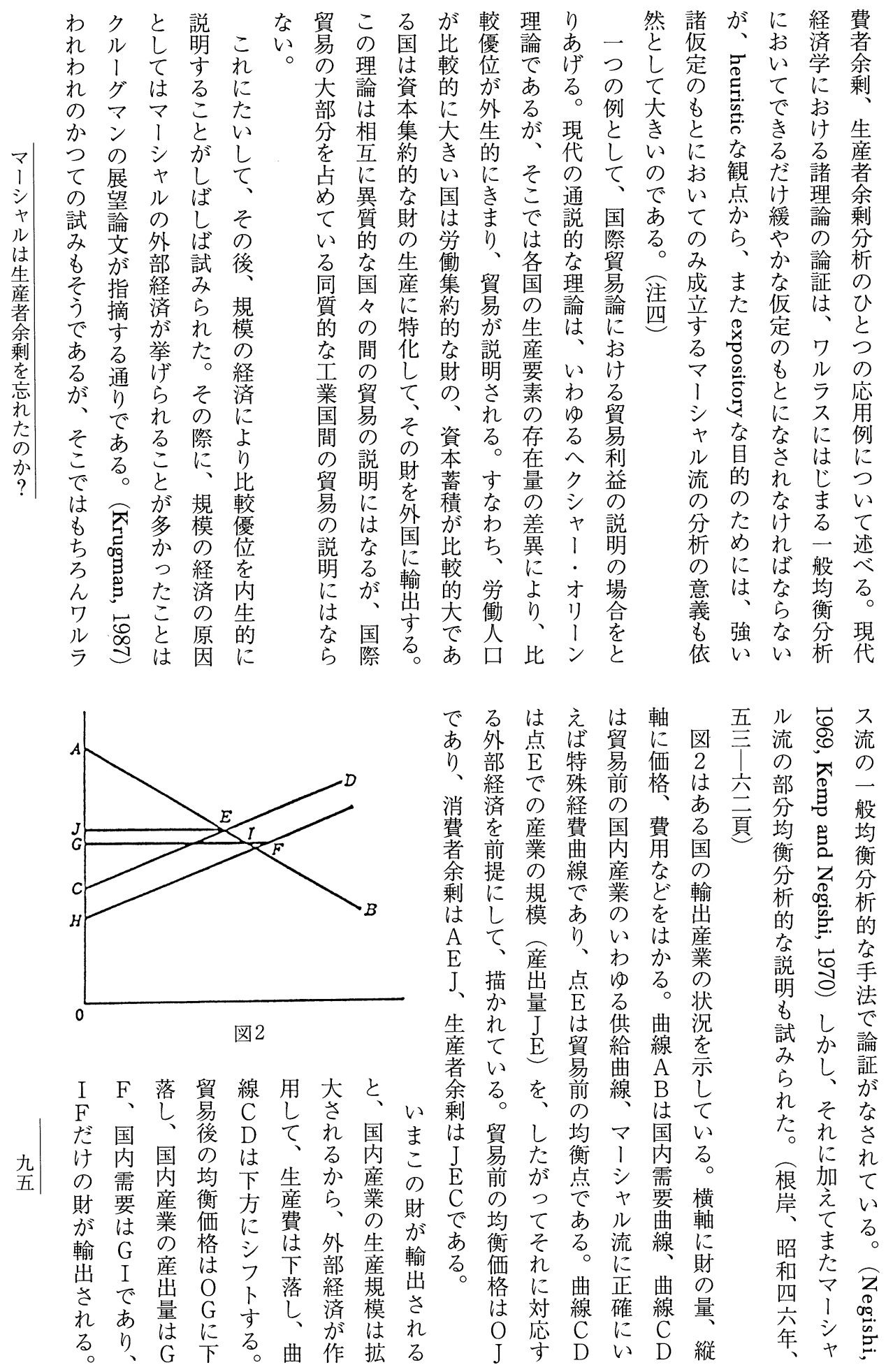




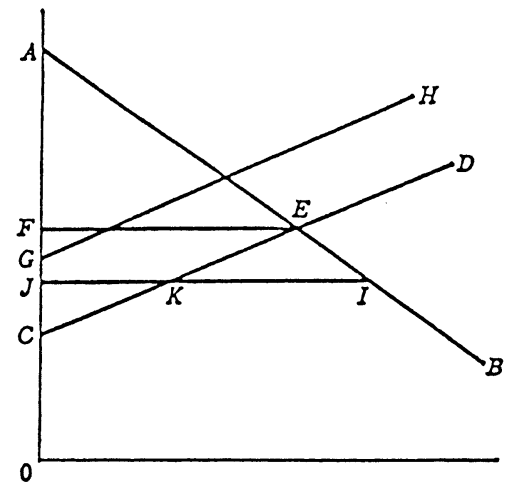

図3

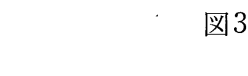

さし生れ生剩まJを拈 $\mathrm{J}$ 昇国

け $\mathrm{E}$ 産る産は少示けにす内

れ $\mathrm{K}$ 者尔者 $\mathrm{A}$ な はし る

ば I 余ら余 Jわすて生り、曲亲

減 J

少 $\mathrm{C}$ 合 費 す 増。 輸。停 線 $\mathrm{C}$ 出

す $\mathrm{K}$ 計者べ加消入国步 $\mathrm{D}$ は は

るよ は 余て す費に 内需場曲方 小

す小もとわが余り要合線にす
$\mathrm{A}$ 部 あ $\mathrm{C}$ よ 消 済、な 3 増者 前格の 輸卞剰 提は意入入る輸

し図経こ者し $\mathrm{O}$ 味 競こ $\mathrm{A}$

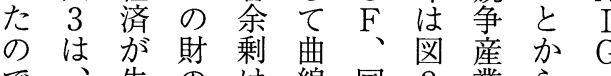

、貿失のは線国 2 業 5 、学

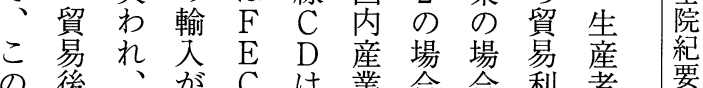

C は 業 合 合 利 者 要

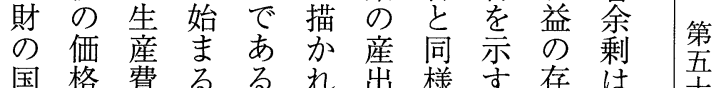

るるれ れ出様す存は量 は 卉

て $\begin{array}{lllll}\text { 量 } & \text { あ } & \text { 在 } & \mathrm{G} & \text { 四 } \\ \text { は } & \text { 横 } & \text { が } & \mathrm{F} & \text { 巻 }\end{array}$

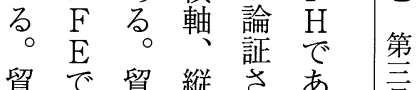

貿で貿 \begin{tabular}{lll|l} 
縦 & さ & あ & 豆 \\
是
\end{tabular}

前そ前曲た

消に均線とず

費 対衡 A に れ

者度点 $\mathrm{B}$ な 8

剰る $\mathrm{E}$ 曲。易
者金三剩イなル、三 余政我合ラい。費わス 剰策々合ラ。費ヤ命 がを々計、彼用ルテイ 存外缃孞のは聥にグ 在部宸減議課増とク し 性厈少論税的っ な補一すはとなての い正九る、補農は議 被的九こ課助業無議 課な九と税金に関は 税最、、意さのた係ピ 産適乙意れ組いでグ 業政呑味た合すあ! の策怘て産せるるに 費とこは業を課。た 用した提税以い 聥ても補案た下す 増弁にな助しけにる は護は。金たを述批 そしマをの単心判 のた 産こシえあによは 業とヤらる提うな ににルれ。案にり おなのた二し、得 ける課産方たマる る。税業、の、㤎 マ生補のスでシ、 1産助余テはヤマ
注㔔場 跡のう図のな在な

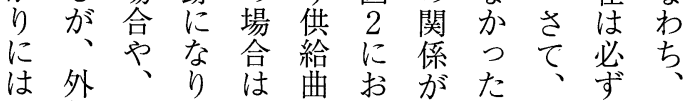
な部長、右線い同こ原し輸 ら経期右下はて、壬原も 入 な済で上が生、の、㻎 保競 いがもがり産曲図原に証争 の存他りの線に因に学産 で在にに曲均 C おの㧍業

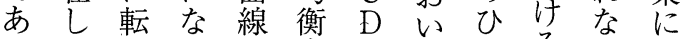

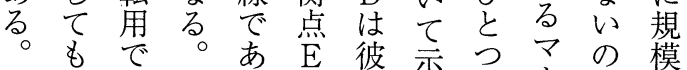
マきつる、年は尔 1なま。 F いれ、シあ経 シ り四なう彼ヤる 済 ヤ土、3 ど特いのル。が ル地生のの殊ないの あ の の 産 場 軌 経い地 鿁 説 る 給代 余はと曲䒼 給が、合

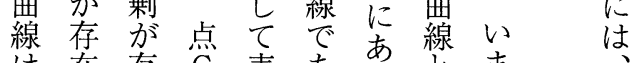

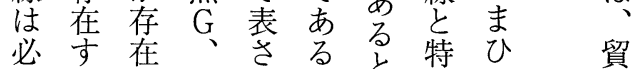
ずる 守 $\mathrm{E}$ れがと殊と晹 し場るなよ経つ も合短どう彼文費明益 右で期 の 


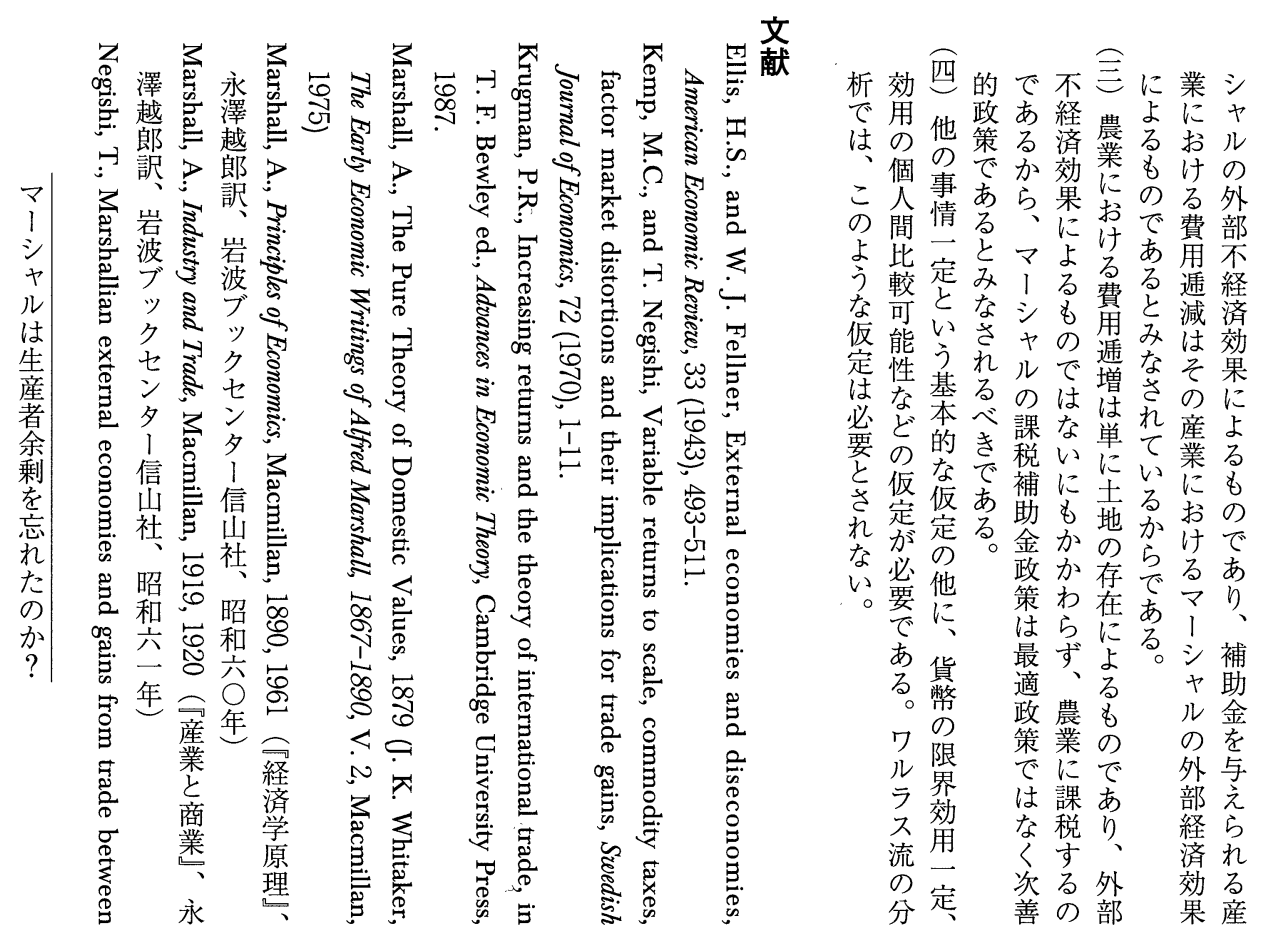

九

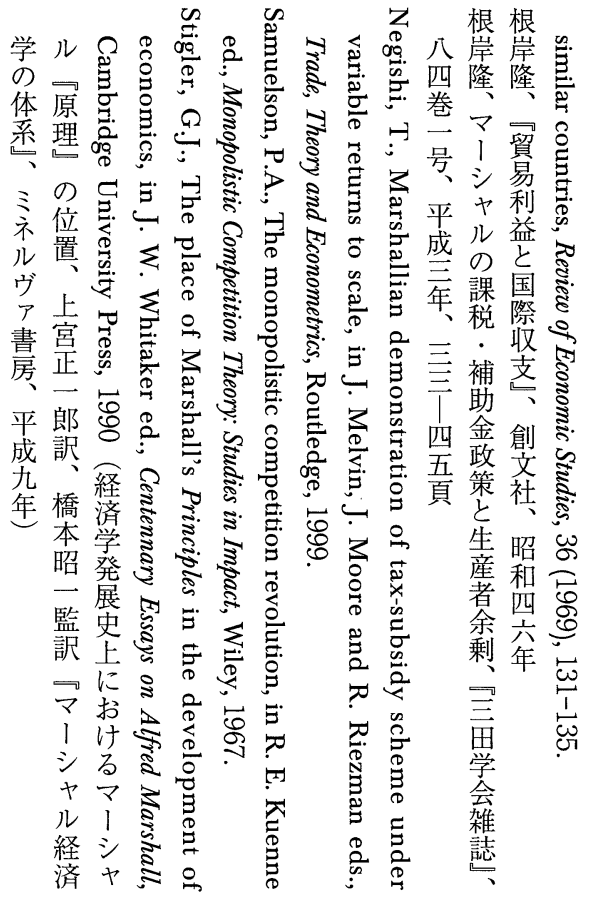




\section{References}

Ellis, H.S., and W. J. Fellner, External economies and diseconomies, American Economic Review, 33 (1943), 493-511.

Marshall, A., The Pure Theory of Domestic Values, 1879 (J. K. Whitaker, The Early Economic Writings of Alfred Marshll, 1867-1890, V.2, Macmillan, 1975)

Marshall, A., Principles of Economics, Macmillan, 1890, 1961.

Negishi, T., Marshallian demonstration of tax-subsidy scheme under variable returns to scale, in J. Melvin, J. Moore and R. Riezman eds., Trade, Theory and Econometrics, Routledge, 1999.

Samuelson, P.A., The monopolistic competition revolution, in R. E. Kuenne ed., Monopolistic Competition Theory: Studies in Impact, New York: Wiley, 1967. 
there is no producers' surplus. Marshall did not forget producers' surplus. $\mathrm{He}$ merely considered the case in which no producers' surplus exists.

Marshall discussed, however, the tax bounty proposal, not only in Principles, but also in The Pure Theory of Domestic Values. In the latter, Marshall, far from forgetting producers' surplus (in the form of land rent), carefully considered the net result of changes in consumers' and producers' surpluses, to insist his tax and bounty plan, i.e., tax on increasing cost industry, even though he clearly recognized that tax receipt is less than the combined loss of consumers' and producers' surpluses. This is because the gains from the bounty to diminishing cost industry, which is financed by the tax, can be larger than the loss in the taxed industry. Nor is it necessary, in spite of Negishi (1999), to restrict the case to manufacturing industries.

The question remains, however, why Marshall, who is very clear in Pure Theory, is not so later in Principles that many modern economists are confused. The reason is that, while Pure Theory is a highly technical theoretical treatise for specialist readers, Principles aims wider circle of non-specialist readers, business men and general intellectuals. In the text of his Principles, Marshall tried to state the main results of his consideration for general readers, while technical points were left in the footnotes and appendices for specialists.

In Principles, the conclusion of the comparison of consumers' surplus, tax and bounty, and the resulting tax bounty proposal, are stated in the text, while the demonstration by the use of Figures 31 and 32 is left to footnotes. The case of tax on agriculture is entirely (both the conclusion and the demonstration by Figure 33) in a footnote. As for the land rent, Marshall in the text merely admits the existence of the problem, "which are not within the scope of the general theory" and does not mention at all whether it increases or decreases as a result of, say, a tax. Marshall considered that the problem of changes in producers' surplus is a footnote matter, which the general readers of Principles can safely ignore. In other words, he judged that the consideration of the problem will not change the conclusion already obtained without taking it into consideration.

We may conclude, then, that Marshall neither forgot the producers' surplus, nor considered the case with no producers' surplus. He recognized the problem but deliberately assumed it away in his general considerations. 


\title{
Did Marshall forget producers' surplus?
}

\author{
by Takashi NEGISHI, M.J.A.
}

Alfred Marshall has been wrongly accused by many modern economic theorists that he forgot to take producers' surplus into consideration in Figure 31 in his Principles (Marshall, 1890, 1961, p. 468, Ellis and Fellner, 1943, Samuelson, 1967), where he proposed the tax and bounty plan. Elsewhere we defended Marshall that Figure 31 can be interpreted as the case of no producers' surplus, in view of his distinction between the supply curve and the particular expenses curve. In other words, Marshall did not forget to consider producers' surplus, but merely considered the case of no producers' surplus (Negishi, 1999).

However, the possibility of such a purely theoretical vindication of Marshall's plan (i.e., the so-called rational reconstruction ) is one thing, but it is quite another to study what Marshall really meant, from the view point of the history of economic thoughts. For the latter purpose, we have to follow Marshall's own historical developments in the consideration of the tax and bounty plan, from The Pure Theory of Domestic Values (1879) to Principles (1890). From such a study, we have to modify our vindication that Marshall did not forget producers' surplus but deliberately assumed it away.

It is true that Marshall did not consider the changes in producers' surplus in Figure 31 (diminishing return) and Figure 32 (increasing return) of Principles and proposed tax and bounty plan. Against Samuelson's criticism, Negishi (1999) defended Marshall, by emphasizing the distinction of the supply curve and the particular expenses curve and the long-run nature of the equilibrium considered. The curve SS' in these figures are called the supply curve, while Marshall demonstrated producers' surplus by using the particular expenses curve (Marshall, 1961, pp. 810-811). In the case of the long run equilibrium of manufacturing industry in which the use of land can be negligible, the particular expenses curve is reduced merely to a horizontal equilibrium price line, and 